\title{
Evaluation of biochemical effects of Casuarina equisetifolia extract on gentamicin-induced nephrotoxicity and oxidative stress in rats. Phytochemical analysis
}

\author{
Walid Hamdy El-Tantawy, ${ }^{1, *}$ Shaza Abdel-Halim Mohamed $^{2}$ and Ekram Nemr Abd Al Haleem ${ }^{3}$ \\ ${ }^{1}$ National Organization For Drug Control \& Research, P.O.29 Cairo, Egypt \\ ${ }^{2}$ Department of Pharmacognosy and 'Department of Pharmacology and Toxicology, Faculty of Pharmacy for Girls, Al-Azhar University, Nasr City, Cairo, Egypt
}

(Received 17 February, 2013; Accepted 27 March, 2013; Published online 10 July, 2013)

\begin{abstract}
Nephrotoxicity is defined as renal dysfunction that arises as result of exposure to external agents such as drugs and environmental chemicals. The present work was undertaken to carry out the phytochemical study and nephroprotective activity of methanolic extract of Casuarina equisetifolia leaves in gentamicin-induced nephrotoxicity in Wistar rats. Flavonoids and phenolic acids were identified and quantified using high performance liquid chromatography. Subcutaneous injection of rats with gentamicin $(80 \mathrm{mg} / \mathrm{kg}$ body weight/day) for six consecutive days induced marked acute renal toxicity, manifested by a significant increase in serum urea, creatinine and uric acid levels, along with a significant depletion of serum potassium level, compared to normal controls. Also oxidative stress was noticed in renal tissue as evidenced by a significant decrease in glutathione level, superoxide dismutase, glutathione-S-transferase activities, also a significant increase in malondialdehyde and nitric oxide levels when compared to control group. Administration of plant extract at a dose of $300 \mathrm{mg} / \mathrm{kg}$ once daily for 4 weeks restored normal renal functions and attenuated oxidative stress. In conclusion, Casuarina equisetifolia leaves extract ameliorates gentamicin-induced nephrotoxicity and oxidative damage by scavenging oxygen free radicals, decreasing lipid peroxidation and improving intracellular antioxidant defense, thus extract may be used as nephroprotective agent.
\end{abstract}

Key Words: Casuarina equisetifolia, nephroprotective, gentamicin, oxidative stress, nephrotoxicity

$\mathrm{N}$ ephrotoxicity can be defined as renal dysfunction that arises as a direct result if exposure to external agents such as drugs and environmental chemicals. Many therapeutic agents have been shown to induce clinically significant nephrotoxicity. ${ }^{(1)}$ Aminoglycoside antibiotics have been widely used for gram-negative infections. However, their nephrotoxicity and their ototoxicity are major limitations in clinical use. ${ }^{(2)}$ Gentamicin (GM) is an aminoglycoside antibiotic which is commonly used for the treatment of infections caused by gram-negative bacteria. ${ }^{(3)}$ However, complications attributable to aminoglycoside toxicity rank as one of the most common reasons for prolonging hospital stays in the developed world, ${ }^{(4)}$ as it has been estimated that up to $30 \%$ of patients treated with GM for more than 7 days show some signs of nephrotoxicity. ${ }^{(5)}$

Reactive oxygen species (ROS) and reactive nitrogen species (RNS) generated by xenobiotics, such as toxicants and drugs, play crucial role in the initiation, and progression of nephrotoxicity and renal injuries. ${ }^{(6)}$ Antioxidant agents can mitigate these deleterious effects in the kidney through modification of the oxidant- antioxidant balances. Numerous recent studies, however, documented that some synthetic antioxidants such as butylated hydroxyl anisole (E320) and butylated hydroxyl toluene (E321) can also induce redox-mediated tissue damages. The toxicities of these compounds include hepatotoxicity, pneumotoxicity, nephrotoxicity, and carcinogenic effects. ${ }^{(7,8)}$ More and more attention has therefore recently been paid to natural antioxidant products with lower adverse side effects.

Recently, there has been renewed interest in medicinal plants that have been found to have certain preventive measures in the treatment of diseases. Many plant products are rich in polyphenolics including tannins and flavonoids, which are group of compounds with diverse in chemical structure, characteristics and widely recognized as naturally occurring antioxidants. Reports revealed that compounds in their natural formulations are more active than isolated form. ${ }^{(9)}$

The plant Casuarina equisetifolia Forst (in Bangladesh known as Jhau gachh, Hari) belongs to the family Casuarinaceae. Extracts of leaves exhibit anticancer properties. ${ }^{(10)}$ Bark is astringent and in stomachache, diarrhea, dysentery and nervous disorders. ${ }^{(1)}$ Seeds are anthelmintic, antispasmodic and antidiabetic. ${ }^{(12)}$

Thus the purpose of the present study is to investigate the nephroprotective effect of methanolic extract of Casuarina equisetifolia leaves on GM-induced nephrotoxicity and oxidative stress in rats and also the phytochemical analysis was carried out.

\section{Materials and Methods}

Chemicals. GM sulfate, available commercially as Epigent ( $80 \mathrm{mg} / 2 \mathrm{ml}$ ampoules), was provided by the Egyptian International Pharmaceutical Industries Co. (EIPICO, 10th of Ramadan City, Egypt). 2,2-Diphenyl-1-picrylyhydrazyl hydrate (DPPH) was procured from Sigma Aldrich (St. Louis, MO). All other chemicals used throughout this study were of pure analytical grades.

Preparation of the extract. Samples of Casuarina equisetifolia were purchased from El-Orman Garden, Ministry of Agriculture, Egypt. The dried leaves of Casuarina equisetifolia $(2 \mathrm{~kg})$ were finely powdered and exhaustively extracted with $100 \%$ methanol, by maceration at room temperature. The crude methanolic extract was evaporated to dryness under reduced pressure. The process of maceration and evaporation was repeated till exhaustion of the plants powder, and then the residues were combined and weighed.

*To whom correspondence should be addressed. E-mail: wldhmdy@yahoo.com 
Phytochemical screening of the extracts. Preliminary phytochemical screening for alkaloids, steroids, carbohydrates, tannins, fixed oils, proteins, triterpenoids, deoxysugar, flavonoid, cyanogenetic and coumarin glycosides carried out on the extract according to the procedures of Khandelwal. ${ }^{(13)}$

Separation and quantification of phenolic compounds. Was conducted on Agilent Technologies 1200 Series Separations Module (GmbH, Germany) equipped with G1322A Vacuum degasser, G1311A Quaternary Pump, G1314B Variable Wavelength Detector (SL), G1328B Manual Injector and G1316A Thermostatted Column Compartment was used for HPLC analysis.

The extract was separated at $35^{\circ} \mathrm{C}$ on a reverse phase HPLC, ACE $5 \mu \mathrm{m}$ C1 8 column with dimensions $250 \times 4.6 \mathrm{~mm}$, detection at $280 \mathrm{~nm}$. The mobile phase used was a gradient of $\mathrm{A}\left(\mathrm{CH}_{3} \mathrm{COOH}\right.$ $2.5 \%), \mathrm{B}\left(\mathrm{CH}_{3} \mathrm{COOH} 8 \%\right)$ and $\mathrm{C}$ (acetonitrile). The best separation was obtained with the following gradient: at $0 \mathrm{~min}, 5 \%$ $\mathrm{B}$; at $20 \mathrm{~min}, 10 \% \mathrm{~B}$. The solvent flow rate was $1 \mathrm{~m} / \mathrm{min}$. The volume injected was $20 \mu \mathrm{l}$. Phenolic compounds were quantified by using standard calibration for each compound and expressed as $\mathrm{mg} / 100 \mathrm{~g}$.

Separation and quantification of flavonoids. This was done using the above mentioned HPLC system and the same column with a mobile phase of methanol: water 1:1 (0-10 min) and $7: 3(10-20 \mathrm{~min})$ at a flow-rate of $1 \mathrm{ml} / \mathrm{min}$ and detection at $339 \mathrm{~nm}$. Each identified flavonoid was quantified by using standard calibration for each compound and expressed as $\mathrm{mg} \%$.

Determination of flavonoid content. Total flavonoidal content was determined by a pharmacopeia method (State Pharmacopeia of USSR, using rutin as a reference compound. One $\mathrm{ml}$ of plant extract in methanol $(10 \mathrm{~g} / \mathrm{L})$ was mixed with $1 \mathrm{ml}$ aluminium trichloride in ethanol $(20 \mathrm{~g} / \mathrm{L})$ and diluted with ethanol to $25 \mathrm{ml}$. The absorption at $415 \mathrm{~nm}$ was read after $40 \mathrm{~min}$ at $20^{\circ} \mathrm{C}$. Blank samples were prepared from $1 \mathrm{ml}$ plant extract and 1 drop acetic acid, and diluted to $25 \mathrm{ml}$. The absorption of rutin solutions was measured under the same conditions. Standard rutin solutions were prepared from $0.05 \mathrm{~g}$ rutin. All determinations were carried out in duplicate. The amount of flavonoids in plant extracts in rutin equivalents (RE) was calculated by the following formula (Eq. 1):

$$
\mathrm{X}=(\mathrm{A} \times \mathrm{m} 0 \times 10) /(\mathrm{A} 0 \times \mathrm{m})
$$

where: $\mathrm{X}$ - flavonoid content, $\mathrm{mg} / \mathrm{g}$ plant extract in RE; A - the absorption of plant extract solution; A0 - the absorption of standard rutin solution; $\mathrm{m}$ - the weight of plant extract, $\mathrm{g} ; \mathrm{m} 0$ the weight of rutin in the solution, $g$.

\section{Determination of antioxidant activity of Casuarina equi-} setifolia extract in vitro.

$D P P H^{*}$ radical scavenging assay. Radical scavenging activity of plant extracts against stable DPPH', was determined spectrophotometrically. When $\mathrm{DPPH}^{-}$reacts with an antioxidant compound, which can donate hydrogen, it is reduced. The changes in colour (from deep-violet to light-yellow) were measured at $520 \mathrm{~nm}$ on a UV/visible light spectrophotometer. ${ }^{(14)}$

Nitric oxide (NO) radical inhibition assay. NO radical inhibition can be estimated by the use of Griess Illosvoy reaction. ${ }^{(15)}$ In this assay, Griess Illosvoy reagent was modified by using naphthyl ethylene diamine dihydrochloride $(0.1 \% \mathrm{w} / \mathrm{v})$ instead of 1 napthylamine $(5 \%)$. The reaction mixture $(3 \mathrm{ml})$ containing sodium nitroprusside $(10 \mathrm{mM}, 2 \mathrm{ml})$, phosphate buffer saline $(0.5 \mathrm{ml})$ and extract $(100-1,000 \mu \mathrm{g})$ was incubated at $25^{\circ} \mathrm{C}$ for $150 \mathrm{~min}$. After incubation, $0.5 \mathrm{ml}$ of the reaction mixture mixed with $1 \mathrm{ml}$ of sulfanilic acid reagent $(0.33 \%$ in $20 \%$ glacial acetic acid) and allowed to stand for 5 min for completing diazotization. Then, $1 \mathrm{ml}$ of naphthyl ethylene diamine dihydrochloride was added, mixed and allowed to stand for $30 \mathrm{~min}$ at $25^{\circ} \mathrm{C}$. A pink coloured chromophore is formed in diffused light. The absorbance of these solutions was measured at $540 \mathrm{~nm}$ against the corresponding blank solutions.
Assay of reducing power. The reductive capability of the extract was quantified by the method of Oyaizu, 1986.(16) One $\mathrm{ml}$ of Extract $(100-1,000 \mu \mathrm{g})$ in distilled water was mixed with $2.5 \mathrm{ml}$ of $0.2 \mathrm{M}$ phosphate buffer ( $\mathrm{pH} 6.6$ ) and $2.5 \mathrm{ml}$ of $1 \%$ potassium ferricyanide $\left[\mathrm{K}_{3} \mathrm{Fe}(\mathrm{CN})_{6}\right]$. The mixture was incubated at $50^{\circ} \mathrm{C}$ for $20 \mathrm{~min}$. Then, the reaction was terminated by adding $2.5 \mathrm{ml}$ of $10 \%$ trichloroacetic acid. The upper layer of solution $(2.5 \mathrm{ml})$ was mixed with distilled water $(2.5 \mathrm{ml})$ and $0.5 \mathrm{ml}$ of $0.1 \% \mathrm{FeCl}_{3}$. Blank reagent is prepared as above without adding extract. The absorbance was measured at $700 \mathrm{~nm}$ in a spectrophotometer against a blank sample. Increased absorbance of the reaction mixture indicated greater reducing power.

Hydroxyl radical ( $\left.{ }^{\circ} \mathrm{OH}\right)$ scavenging assay. The reaction mixture $(3 \mathrm{ml})$ containing $1 \mathrm{ml} \mathrm{FeSO} 4(1.5 \mathrm{mM}), 0.7 \mathrm{ml}$ hydrogen peroxide $(6 \mathrm{mM}), 0.3 \mathrm{ml}$ sodium salicylate $(20 \mathrm{mM})$ and varying concentrations of the extract $(2-10 \mu \mathrm{g})$ were taken. After incubation for $1 \mathrm{~h}$ at $37^{\circ} \mathrm{C}$, the absorbance of the hydroxylated salicylate complex was measured at $562 \mathrm{~nm} .^{(17)}$

\section{Experimental design.}

Animals and experimental protocol. Swiss male albino mice (20-25 g) were used for the acute study LD50 of methanolic extract of the plant under investigation was determined according to Behrens and Karber. ${ }^{(18)}$

Acute toxicity study. It was found that the tested extracts were not mortal even at a dose of $3,000 \mathrm{mg} / \mathrm{kg}$ and consequently the dose $300 \mathrm{mg} / \mathrm{kg}$ was selected for the study.

Thirty six male Wister albino rats weighing (150-200) g were used for this study. The animals were housed in a temperature $\left(25 \pm 1^{\circ} \mathrm{C}\right)$, humidity controlled room and a $12 \mathrm{~h}$ light-dark cycle (lights on at 6:00). Rats were allowed free access to tap water and standard pellet diet. The institutional Animal Ethics Committee approved all experimental protocols. The animals were classified into 6 groups, each of 6 as follows:

- Control group (C): Rats received distilled water.

- GM: Rats received subcutaneous injection of GM $(80 \mathrm{mg} / \mathrm{kg}$ body weight/day) for 6 consecutive days.

Curative groups:

- GM and Casuarina equisetifolia extract treated group, $(\mathrm{GM}+\mathrm{E})$ : Rats received subcutaneous injection of $\mathrm{GM}(80 \mathrm{mg} / \mathrm{kg}$ body weight/day) for 6 consecutive days, followed by oral administration of Casuarina equisetifolia extract a dose of $300 \mathrm{mg} / \mathrm{kg}$ once daily for 4 weeks.

- GM and Silymarin (Reference drug) treated group, $(\mathrm{GM}+\mathrm{R})$ : Rats received subcutaneous injection of $\mathrm{GM}(80 \mathrm{mg} / \mathrm{kg}$ body weight/day) for 6 consecutive days, followed by oral administration of Silymarin a dose of $50 \mathrm{mg} / \mathrm{kg}$ once daily for 4 weeks.

Protective groups:

- Casuarina equisetifolia extract and GM treated group $(\mathrm{E}+\mathrm{GM})$ : Rats received oral administration of Casuarina equisetifolia extract at a dose of $300 \mathrm{mg} / \mathrm{kg}$ once daily for 4 weeks, followed by subcutaneous injection of $\mathrm{GM}(80 \mathrm{mg} / \mathrm{kg}$ body weight/day) for 6 consecutive days.

- Silymarin (Reference drug) and GM treated group (R + GM): Rats received oral administration of Silymarin at a dose of $50 \mathrm{mg} / \mathrm{kg}$ once daily for 4 weeks, followed by subcutaneous injection of GM ( $80 \mathrm{mg} / \mathrm{kg}$ body weight/day) for six consecutive days.

Blood collection and biochemical assays. Fasting blood samples were withdrawn from the retro-orbital vein of each animal using a glass capillary tube after fasting period of $12 \mathrm{~h}$. The blood samples allowed to coagulate and then centrifuged at $3,000 \mathrm{rpm}$ for $20 \mathrm{~min}$. The separated sera were used for the estimation of serum activities of alanine transaminase (ALT), aspartate transaminase (AST) by using commercial kits (Quimica Clinica Aplicada, Spain). Serum urea and creatinine level was determined using commercial kits purchased from Stanbio, Boerne, TX. Serum potassium and uric acids concentrations were evaluated using kits from Biodiagnostic, Egypt. Serum vitamin C level was assayed using the method described by Jagota and Dani. ${ }^{(19)}$ 
Preparation of renal homogenate. The whole kidney was accurately weighed and homogenized in ice-saline to prepare a $10 \%(\mathrm{w} / \mathrm{v})$ tissue homogenate. The homogenate was used for the determination of malondialdehyde level (MDA) and reduced glutathione level (GSH), superoxide dismutase activity (SOD), glutathione-S-transferase activity (GST) and nitric oxide level (NO).

Determination of protein content. The protein content of kidney homogenates was evaluated by following the method of Lowry et al. ${ }^{(20)}$ and using bovine serum albumin as a standard.

\section{Biochemical analysis in kidney homogenate.}

Determination of lipid peroxidation. MDA, as lipid peroxidation end product within kidney tissues, was quantified via the established measurement of the level of thiobarbituric acid reactive substances (TBARS). An aliquot of $0.5 \mathrm{ml}$ of $10 \%$ homogenate (or standard) was pipetted into a $10 \mathrm{ml}$ centrifuge tube followed by the addition of $3 \mathrm{ml}$ of $1 \%$ orthophophoric acid and $1 \mathrm{ml}$ of $0.6 \%$ thiobarbituric acid. After heating for $45 \mathrm{~min}$ in a boiling water bath, the mixture was then cooled and $4 \mathrm{ml}$ of $\mathrm{n}$ butanol was added and mixed vigorously. The upper butanol layer was separated by centrifugation and absorbance was measured at $535 \mathrm{~nm}$ and $520 \mathrm{~nm}$ against a reagent blank. ${ }^{(21)}$

Determination of GSH level. GSH level in renal tissue homogenates was measured by the method of Ellman. ${ }^{(22)}$ Trichloroacetic acid $(5 \%)$ was added to adequate dilution of tissue homogenates $(0.5 \mathrm{ml})$ to precipitate the protein content in the samples. Then, this mixture was centrifuged at 10,000 g, $5 \mathrm{~min}$ and the supernatant was recovered. Finally, 5,5'-dithiobis(2-nitrobenzoic acid) solution was added to the reaction mixtures, and the absorbance was recorded at $412 \mathrm{~nm}$ using spectrophotometer.

Determination of SOD activity. SOD activity in renal tissues was determined by the method of Marklund and Marklund.(23) Pyrogallol $(24 \mathrm{mM})$ was prepared in $10 \mathrm{mM} \mathrm{HC1}$ and kept at $4^{\circ} \mathrm{C}$ before use. Stock catalase solution $(30 \mu \mathrm{M})$ was prepared

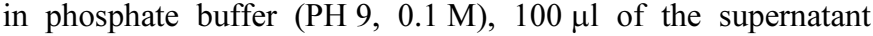
was added to Tris HC1 buffer ( $\mathrm{pH} 7.8,0.1 \mathrm{M}$ ) containing $25 \mu \mathrm{l}$ pyrogallol and $10 \mu \mathrm{l}$ catalase. The final volume was adjusted to $3 \mathrm{ml}$ using the same buffer solution. Changes in the absorbance at $420 \mathrm{~nm}$ were recorded at $1 \mathrm{~min}$. interval for $3 \mathrm{~min}$. Data were expressed as U/mg protein.

Determination of GST activity. GST activity in renal tissues was assayed according to the method of Habig et al. ${ }^{(24)}$ In brief, $2.8 \mathrm{ml}$ of $0.1 \mathrm{M}$ phosphate buffer $\mathrm{pH} 6.5$, glutathione $100 \mu \mathrm{l}$ and 1-chloro 2,4-dinitrobenzene $100 \mu \mathrm{l}$ was mixed. The reaction was started by the addition of $25 \mu \mathrm{l}$ of $10 \%$ homogenate fraction. The change in absorbance was observed by continuous recording at $340 \mathrm{~nm}$ at $1 \mathrm{~min}$ intervals for $3 \mathrm{~min}$, the data were expressed as $\mathrm{nmol} / \mathrm{min} /$ mg protein.

Determination of NO content. NO level in renal tissue homogenates was determined according to the method of Green et al. ${ }^{(25)}$ The assay is based on the diazotization of sulfanilic acid with nitric oxide at acidic $\mathrm{pH}$ and subsequent coupling with $\mathrm{N}$-(10naphthyl)-ethylenediamine to yield an intensely pink colored product that is measured spectrophotometrically at $540 \mathrm{~nm}$. Sodium nitrite was used as standard.

Statistical analysis. Statistical analysis of differences between means was carried out using ANOVA, followed by the least significant difference (LSD) test for multiple comparisons using SPSS for Windows software, ver. 6.0 (Chicago, IL); $p<0.05$ was considered statistically significant for all tests.

\section{Results}

Phytochemical analysis of methanolic extract of Casuarina equisetifolia leaves revealed the presence of tannins, flavonoids, alkaloids, phenolics, terpenoids and steroids (Table 1).

Identification of quantification of phenolic compounds. Fig. 1 represents the separation of phenolic compounds of
Table 1. Phytochemical analysis of methanolic extract of Casuarina equisetifolia leaves

\begin{tabular}{lc}
\hline Chemical group & Identification \\
\hline Tannins & ++++ \\
Flavonoids & +++ \\
Saponins & - \\
Alkaloids & + \\
Phenolics & ++++ \\
Terpenoids & + \\
Steroids & + \\
\hline
\end{tabular}

Casuarina equisetifolia leaves extract. HPLC analysis of the total phenolic contents of methanolic extract of the aerial parts of Casuarina equisetifolia revealed the presence of 9 phenolic compounds as gallic acid, protochatechuic acid, para-coumaric acid, chlorogenic acid, salicylic acid, benzoic acid, catechol, pyrogallol and chrysin in concentration of $(21.41,13.15,0.73,129.42,3.14$, $181.39,16.17,1,049.9$ and $3.04 \mathrm{mg} / 100 \mathrm{~g}$ plant extract respectively). Pyrogallol represented the highest concentration of the identified phenolic compounds while para-coumaric acid was the lowest concentration (Table 2).

Identification of quantification of flavonoids. Fig. 2 represents the separation of flavonoids and flavonols of Casuarina equisetifolia leaves extract. HPLC analysis of the total flavonoidal contents of the same plant extract showed the presence of flavonol constituents as quercitin, rutin and kampferol, flavone constituents as hesperitin and apigenin and flavanone constituent as narenginin in the concentration of $(837.9,834.6,399.2,206.2,59.9$ and $384.8 \mathrm{mg} / 100 \mathrm{~g}$ plant extract respectively). Quercitin represented the highest concentration flavonoidal compound while apigenin was the lowest concentration, (Table 3).

The content of flavonoidal compounds ( $\mathbf{m g} \%$ ). The flavonoidal content was found to be $11.66 \pm 0.2 \mathrm{mg} \%$ rutin equivalent.

DPPH ${ }^{\bullet}$ radical scavenging activity. Casuarina equisetifolia extract scavenges DPPH radicals in a dose dependent manner $(10-100) \mu \mathrm{g}$, with a $50 \%$ inhibition (IC50) at a concentration of $18 \mu \mathrm{g}$ (Fig. 3).

NO radical inhibition. The scavenging of NO by extract was increased in a dose dependent manner as illustrated in Fig. 4. At concentration of $800 \mu \mathrm{g}$ of extract $50 \%$ of $\mathrm{NO}$ generated by incubation was scavenged.

Hydroxyl radical $(\cdot \mathrm{OH})$ scavenging activity. The extract of Casuarina equisetifolia exhibited a significant dose dependent inhibition of $\mathrm{OH}$ activity, with a $50 \%$ inhibition (IC50) at a concentration of $4 \mu \mathrm{g}$ (Fig. 5).

Reducing power. The reducing power of extract of Casuarina equisetifolia was very potent and the reducing power of the extract was increased with concentration of sample. The plant extract could reduce the most $\mathrm{Fe}^{3+}$ ions (Fig. 6).

Effect of Casuarina equisetifolia extract on GM-induced renal dysfunction. Subcutaneous injection of normal rats with GM caused a significant increase in serum urea, creatinine, uric acid levels and a significant reduction in serum potassium concentration with respect to normal controls, $p<0.05$. Whereas in both protective and curative groups the oral administration of Casuarina equisetifolia extract as well as Silymarin (reference drug) to GM-intoxicated rats significantly normalized renal dysfunction, the effect was prominent in the protective groups (Table 4). The treatment of rats with Casuarina equisetifolia extract showed normal serum ALT and serum AST activities indicating its safety.

Effect of Casuarina equisetifolia extract and/or GM treatment on GST, SOD activities and GSH level in renal homogenate. GM intoxication caused a significant decrease in renal GST, SOD activities and GSH level as compared with normal controls, $p<0.05$. Either treatment with Casuarina equisetifolia ex- 


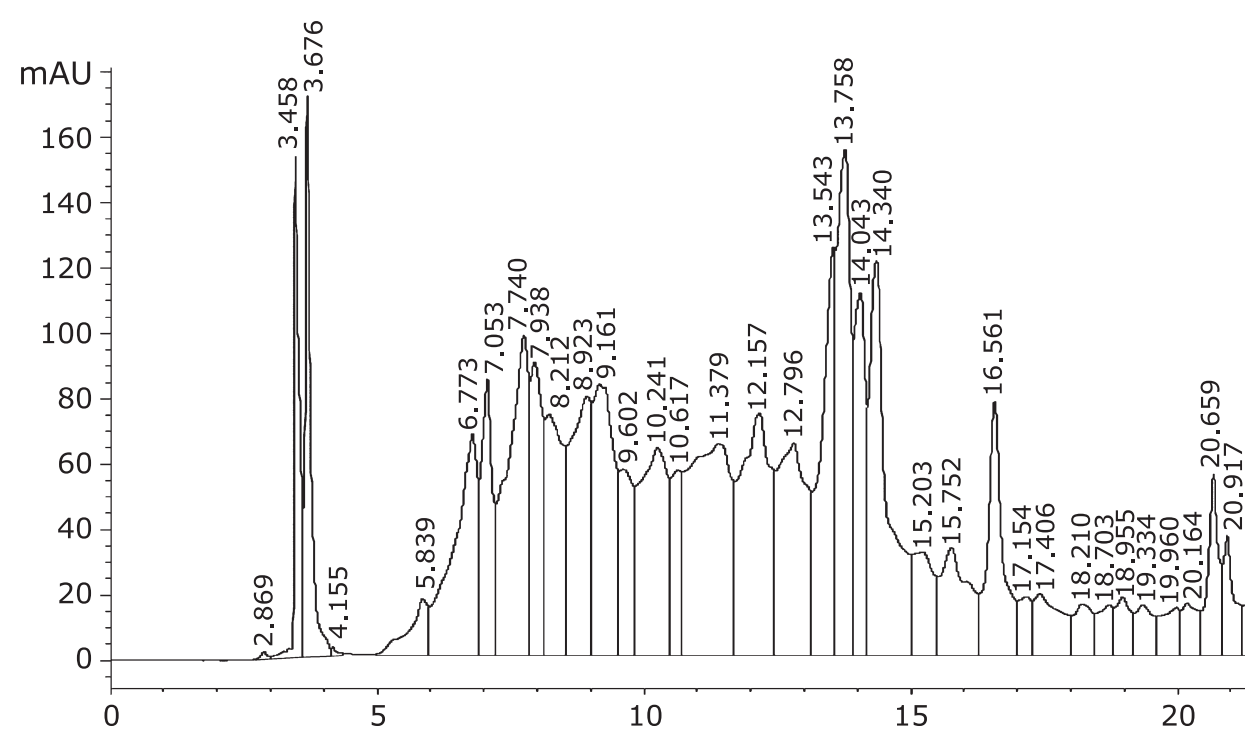

Fig. 1. HPLC chromatograms of identified phenolic compounds of Casuarina equisetifolia leaves extract separated by RP HPLC; Pyrogallol $\left(R_{t}=6.7 \mathrm{~min}\right)$, Gallic $\left(R_{t}=7 \mathrm{~min}\right)$, Protocatechuic $\left(R_{t}=8.2 \mathrm{~min}\right)$, Chlorogenic $\left(R_{t}=8.7 \mathrm{~min}\right)$, Catechol $\left(R_{t}=8.9 \mathrm{~min}\right)$, Salicylic $\left(R_{t}=11.3 \mathrm{~min}\right), P$-Coumaric $\left(R_{t}=12.79 \mathrm{~min}\right)$, Benzoic $\left(R_{t}=13.54 \mathrm{~min}\right)$, Chrysin $\left(R_{t}=18.2 \mathrm{~min}\right)$.

Table 2. Identified phenolics in methanolic extract of Casuarina equisetifolia leaves

\begin{tabular}{lc}
\hline Test items & $\begin{array}{c}\text { Concentration } \\
(\mathrm{mg} / 100 \mathrm{~g})\end{array}$ \\
\hline Gallic & 21.41 \\
Protocatechuic & 13.15 \\
P-Coumaric & 0.73 \\
Chlorogenic & 129.42 \\
Catechol & 16.17 \\
Pyrogallol & 1049.9 \\
Salicylic & 3.14 \\
Chrysin & 3.04 \\
Benzoic & 181.39 \\
\hline
\end{tabular}

tract as well as Silymarin before GM (protective group, E + GM) or after GM (curative group, $\mathrm{GM}+\mathrm{E}$ ) revealed a significant increase in GST, SOD activities and GSH level as compared to GM intoxicated rats, $p<0.05$, (Table 5).

Effect of Casuarina equisetifolia extract and/or GM treatment on MDA and NO level in renal homogenate. GM intoxication caused a significant increase in MDA and NO level as compared with normal controls, $p<0.05$. Either treatment with Casuarina equisetifolia extract as well as Silymarin revealed a significant decrease in MDA and NO levels as compared to GM intoxicated one $(p<0.05$, Table 5$)$.

\section{Discussion}

The present study demonstrated protective and curative effects of Casuarina equisetifolia leaves extract, on GM-induced nephrotoxicity, in line with the consideration that oxygen-free radicals are important mediators of GM-induced acute renal failure.

In the present study, GM administration caused marked renal dysfunction as evidenced by the significant increase in serum urea, creatinine and uric acid levels along with a significant depletion in serum $\mathrm{K}^{+}$level. It is well documented that GM nephrotoxicity in experimental animals causes acute renal failure and reduction in serum $\mathrm{K}^{+}$levels. ${ }^{(26,27)}$
Recent evidence indicated that ROS are the potential mediators involved in GM-induced renal dysfunction. GM has been shown to enhance generation of superoxide anion $\left(\mathrm{O}_{2}{ }^{--}\right)$, peroxynitrite anion $\left(\mathrm{ONOO}^{-}\right)$, hydrogen peroxide $\left(\mathrm{H}_{2} \mathrm{O}_{2}\right)$, and $\left({ }^{\circ} \mathrm{OH}\right)$ production from renal cortical mitochondria. The interaction between $\mathrm{O}_{2}{ }^{--}$and $\mathrm{H}_{2} \mathrm{O}_{2}$ in the presence of a metal catalyst (iron) leads to the generation of toxic ${ }^{\circ} \mathrm{OH}$, which induces peroxidation of the polyenoic lipids of the endoplasmic reticulum and subsequent generation of secondary free radicals derived from these lipids. This destructive lipid peroxidation leads to breakdown of membrane structure and function. Further decomposition of peroxidized lipids yields a wide variety of end products, including MDA. ${ }^{(28)}$ This GMinduced oxidative stress is the central pathway responsible for nephrotoxicity. ${ }^{(29,30)}$

In our work, oral administration of Casuarina equisetifolia leaves extract to GM-intoxicated rats normalized serum urea, Creatinine, uric acid and $\mathrm{K}^{+}$levels, suggesting that the extract under investigation may introduce protection against GM-induced nephrotoxicity, possibly by attenuating the oxidative stress induced by administration of GM.

GSH depletion is a common consequence of increased formation of ROS. An explanation to cellular GSH depletion after GM intoxication is the increased consumption of GSH in non-enzymatic removal of oxygen radicals, or the oxidation of sulfhydryl group existing at the active site of the enzyme molecule. ${ }^{(31)}$

Also, it has been reported that depletion of cellular GSH level results in a concomitant decrease in glutathione-related enzymes activity. ${ }^{(32)}$ Oxidative stress in renal tissue leads to diminished SOD activity. ${ }^{(33)}$

Most of the antioxidant enzymes become inactive in response to oxidative stress. ${ }^{(34)}$ The decrease of SOD and GST activities in the kidney tissues by GM administration in the present investigation run in parallel to the study of Pedraza-Chaverri et al. ${ }^{(35)}$ However, Free radicals are causative factors for aminoglycosides (GM) induced renal toxicity. ${ }^{(36)}$ It has demonstrated that GM generates ROS that mediate biomolecules oxidation in the kidney. ${ }^{(37)}$ The excessive ROS can damage the protein sensitive thiols. Therefore, GM inhibits the activities of antioxidant enzymes, GST and SOD and depletes thiol cellular content. ${ }^{(38)}$ In our work, Casuarina equisetifolia leaves extract consumption improves GSH content and SOD as well as GST activities. These results demonstrated 


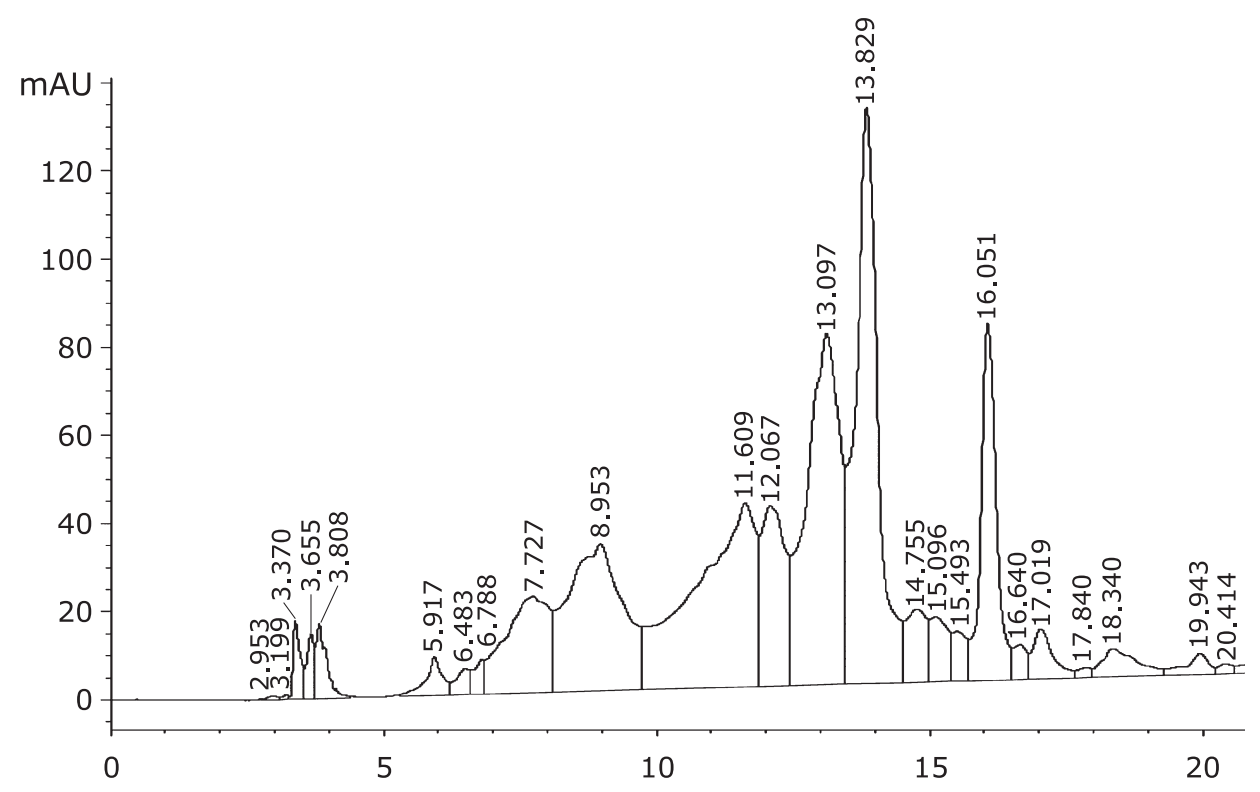

Fig. 2. HPLC chromatograms of identified flavonoidal compounds of Casuarina equisetifolia leaves extract separated by RP HPLC; Rosmarinic $\left(R_{t}=11.24 \mathrm{~min}\right)$, Hesperetin $\left(R_{t}=11.6 \mathrm{~min}\right)$, Rutin $\left(R_{t}=12.06 \mathrm{~min}\right.$, Quercitin $\left(R_{t}=13.09 \mathrm{~min}\right)$, Narenginin $\left(R_{t}=14.1 \mathrm{~min}\right), \mathrm{Kampferol}\left(R_{t}=14.75 \mathrm{~min}\right)$, Apignen $\left(R_{\mathrm{t}}=15.49 \mathrm{~min}\right)$.

Table 3. Identified flavonoids in methanolic extract of Casuarina equisetifolia leaves

\begin{tabular}{lc}
\hline Test items & $\begin{array}{c}\text { Concentration } \\
(\mathrm{mg} / 100 \mathrm{~g})\end{array}$ \\
\hline Rutin & 834.6 \\
Rosmarinic & 384.6 \\
Quercitin & 837.9 \\
Hesperetin & 206.2 \\
Narenginin & 384.8 \\
Apignen & 59.9 \\
Kampferol & 399.2 \\
\hline
\end{tabular}

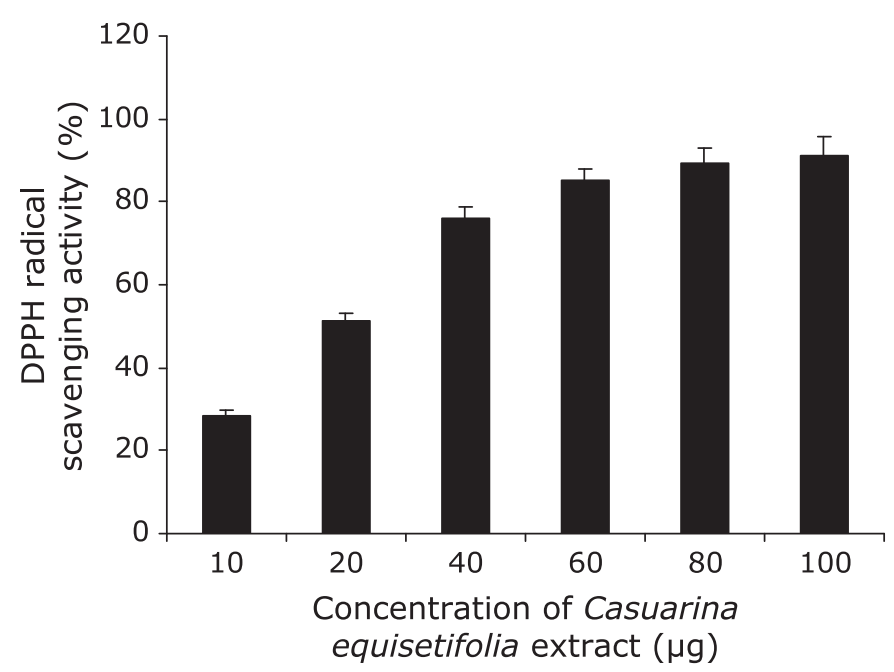

Fig. 3. Effect of different concentrations of Casuarina equisetifolia extract on scavenging activity of DPPH radicals. Values are expressed as mean \pm SEM of three experiments.

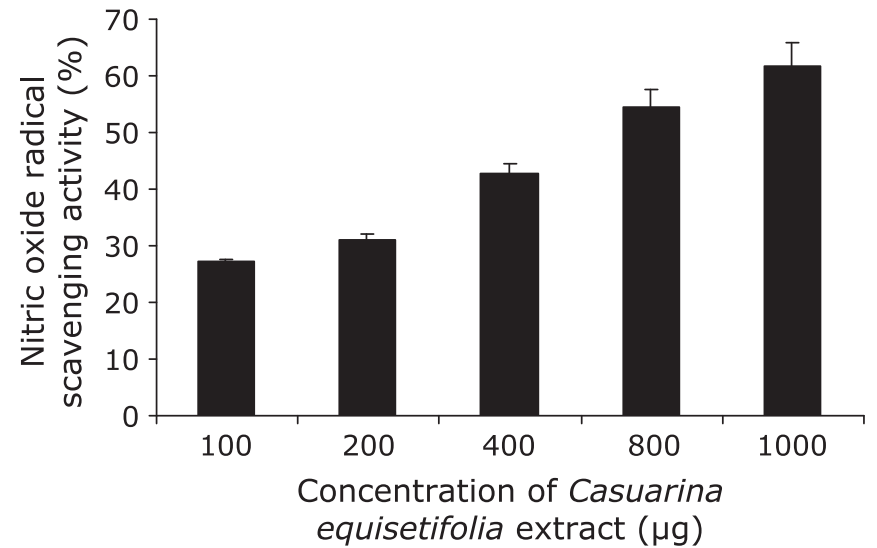

Fig. 4. Effect of different concentrations of Casuarina equisetifolia extract on scavenging activity of NO radicals. Values are expressed as mean \pm SEM of three experiments.

that Casuarina equisetifolia leaves extract significantly enhanced antioxidant defense against GM induced oxidative damage in renal tissues. This may be attributed to free radical scavenging property of extract as well as direct antioxidant action. ${ }^{(39)}$

The findings in the current study is consistent with data of Alqasoumi et al., ${ }^{(40)}$ the author investigated the possible protective effect of water spinach Ipomea aquatica ethanol extract against GM-induced nephrotoxicity in Wistar albino rats. The author found that concomitant administration of Ipomea aquatica extract attenuated the harmful effects of GM both by inhibiting freeradical formation and/or by restoration of the antioxidant systems. The author attributed the protective effect of Ipomea aquatica to the presence of flavonoids and tannins that are known to possess potent antioxidant and free radical scavenging properties.

In a previous study was conducted by Shirwaikar et al., ${ }^{(41)}$ the author studied the protective activity of ethanolic extract of Aerva lanata in cisplatin and GM-induced nephrotoxicity in male Wistar 


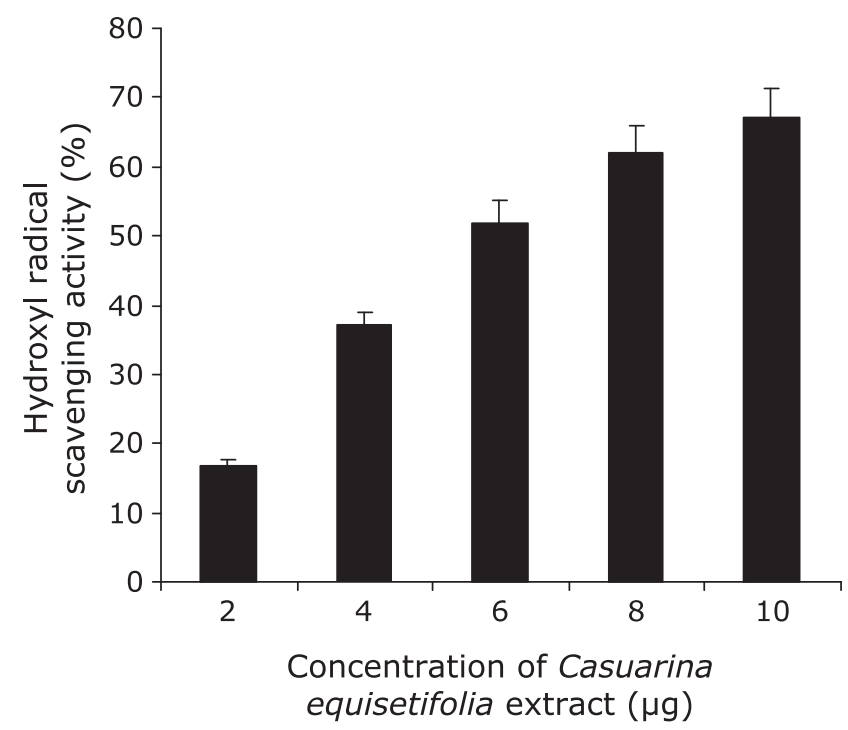

Fig. 5. Effect of different concentrations of Casuarina equisetifolia extract on scavenging activity of hydroxyl radicals. Values are expressed as mean \pm SEM of three experiments.

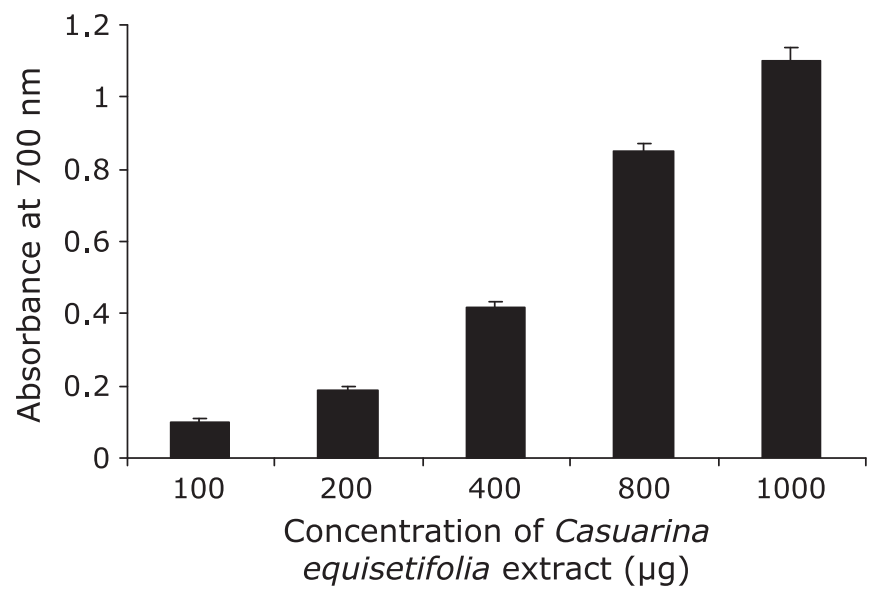

Fig. 6. Effect of different concentrations of Casuarina equisetifolia extract on the reducing power. Values are expressed as mean \pm SEM of three experiments.

Table 4. Effect of Casuarina equisetifolia extract and/or GM treatment on studied serum biochemical parameters

\begin{tabular}{|c|c|c|c|c|c|c|c|}
\hline Group & $\begin{array}{c}\text { Urea } \\
\text { (mg/dl) }\end{array}$ & $\begin{array}{c}\text { Creatinine } \\
(\mathrm{mg} / \mathrm{dl})\end{array}$ & $\begin{array}{l}\text { Uric acid } \\
\text { (mg/dl) }\end{array}$ & $\begin{array}{l}\text { Potassium } \\
\text { (mmol/L) }\end{array}$ & $\begin{array}{c}\text { Vitamin } C \\
(\mathrm{mg} / \mathrm{dl})\end{array}$ & $\begin{array}{l}\text { SALT } \\
\text { (U/L) }\end{array}$ & $\begin{array}{l}\text { SAST } \\
\text { (U/L) }\end{array}$ \\
\hline $\mathrm{C}$ & $23.43 \pm 1.2$ & $0.43 \pm 0.014$ & $1.47 \pm 0.094$ & $5.29 \pm 0.4$ & $1.39 \pm 0.15$ & $26.6 \pm 2$ & $52.1 \pm 4.9$ \\
\hline GM & $119 \pm 10.2^{*}$ & $1.97 \pm 0.063 *$ & $2.53 \pm 0.16^{*}$ & $4.07 \pm 0.03^{*}$ & $0.82 \pm 0.02 *$ & $27.8 \pm 2.2$ & $54.4 \pm 3.9$ \\
\hline $\mathrm{GM}+\mathrm{E}$ & $33 \pm 2 *+ \pm * *$ & $0.43 \pm 0.01 * *$ & $1.21 \pm 0.11 * *$ & $5.86 \pm 0.26 * *$ & $1.49 \pm 0.12 * *$ & $29 \pm 1.9$ & $53 \pm 5$ \\
\hline$E+G M$ & $23.88 \pm 1 * *$ & $0.44 \pm 0.02 * *$ & $0.92 \pm 0.1 * * *$ & $4.83 \pm 0.04 * \star \S$ & $1.56 \pm 0.099 * *$ & $28.2 \pm 2.5$ & $52 \pm 5.1$ \\
\hline $\mathrm{GM}+\mathrm{R}$ & $29.4 \pm 2.3 * t * *$ & $0.39 \pm 0.01 * *$ & $1.0 \pm 0.03 * * *$ & $4.9 \pm 0.15^{\star \star \S}$ & $1.34 \pm 0.12 * *$ & $29.3 \pm 2.4$ & $55.6 \pm 4.89$ \\
\hline $\mathrm{R}+\mathrm{GM}$ & $27.31 \pm 1.5^{* *}$ & $0.41 \pm 0.007 * *$ & $1.1 \pm 0.04 * * *$ & $4.55 \pm 0.02 * \S * *$ & $1.48 \pm 0.04 * *$ & $28.4 \pm 2.3$ & $51 \pm 3.78$ \\
\hline
\end{tabular}

Results are expressed as mean \pm SE. *Significantly different from control group, **Significantly different from $\mathrm{GM}$ treated group, ${ }^{\dagger} \mathrm{Groups} \mathrm{GM}+\mathrm{E}$ and $G M+R$ are significantly different from group $E+G M,{ }^{\ddagger} G$ roup $R+G M$ is significantly different from group $G M+E$, ${ }^{\S} G$ roups $E+G M, G M+R$ and $R+G M$ are significantly different from group $G M+E$.

Table 5. Effect of Casuarina equisetifolia extract and/or GM treatment on GST, SOD activities, GSH, MDA and NO level in renal homogenate

\begin{tabular}{|c|c|c|c|c|c|}
\hline Group & $\begin{array}{c}\text { GST } \\
\text { (nmol/min } / \mathrm{mg} \text { protein) }\end{array}$ & $\begin{array}{c}\text { SOD } \\
\text { (U/mg protein) }\end{array}$ & $\begin{array}{c}\text { GSH } \\
\text { (nmol/mg protein) }\end{array}$ & $\begin{array}{c}\text { MDA } \\
\text { (nmol/g tissue) }\end{array}$ & $\begin{array}{c}\mathrm{NO} \\
(\mu \mathrm{mol} / \mathrm{g} \text { wt tissue })\end{array}$ \\
\hline C & $45.6 \pm 1.9$ & $55.2 \pm 1.27$ & $20 \pm 0.78$ & $52.6 \pm 1.04$ & $125 \pm 3.95$ \\
\hline GM & $38.8 \pm 1 *$ & $46.2 \pm 1.4^{*}$ & $15.9 \pm 0.45^{*}$ & $60.4 \pm 0.6^{*}$ & $140 \pm 1.38 *$ \\
\hline $\mathrm{GM}+\mathrm{E}$ & $43.8 \pm 064 * *$ & $53.1 \pm 1.1 * \star \S$ & $19.4 \pm 0.49 * *$ & $54 \pm 0.75^{* *}$ & $123 \pm 2.75 * *$ \\
\hline $\mathrm{E}+\mathrm{GM}$ & $44.3 \pm 0.89 * *$ & $52.4 \pm 0.76 * \star \S$ & $19.2 \pm 0.5^{* *}$ & $54.6 \pm 0.7 * *$ & $126 \pm 2.39 * *$ \\
\hline $\mathrm{GM}+\mathrm{R}$ & $48.8 \pm 0.6 * *+\neq$ & $59 \pm 1.86^{* *}$ & $19.9 \pm 0.86 * *$ & $52.4 \pm 0.8 * *$ & $125 \pm 3.2 * *$ \\
\hline $\mathrm{R}+\mathrm{GM}$ & $47.2 \pm 1 * *+$ & $58.8 \pm 1.8 * *$ & $21 \pm 0.8^{* *}$ & $53.4 \pm 0.7 * *$ & $126 \pm 3.5^{* *}$ \\
\hline
\end{tabular}

Results are expressed as mean $\pm S E$. *Significantly different from control group $* *$ Significantly different from (GM) treated group, ${ }^{\dagger} \mathrm{Groups} G M+R$ and $R+G M$ are significantly different from group $G M+E,{ }^{\ddagger} G r o u p ~ G M+R$ is significantly different from group $E+G M,{ }^{5} G r o u p s ~ G M+E$ and $E+G M$ are significantly different from groups $\mathrm{GM}+\mathrm{R}$ and $\mathrm{R}+\mathrm{GM}$.

albino rats. The author found that the ethanol extract of Aerva lanata was found to normalize the raised blood urea, serum creatinine and bring about marked recovery in kidneys. The author mentioned that flavonoids such as kaempferol 3-rhamnoside and kaempferol 3-rhamnogalactoside have been reported to be present in Aerva lanata. Flavonoids are well known potent antioxidant and free radical scavengers. Hence, the probable mechanism of nephroprotection by Aerva lanata may be attributed to its antioxidant and free radical scavenging property.
Natural antioxidants such as flavonoids and polyphenols are believed to possess antioxidant properties due to their reducing and chelating capabilities. Flavonoids and polyphenols are secondary plant metabolites that are widely distributed in fruits, leaves, bark, and other parts in plants with free radical scavenging abilities. ${ }^{(42)}$

In the present study, there was a significant increase in renal NO in GM-treated rats. The rise of renal NO in GM-treated rats has been previously reported. ${ }^{(43)}$ This supported by the finding of 
Abdelaziz and Kandeel. ${ }^{(44)}$ The authors demonstrated that NO was increased by GM induced renal toxicity.

Moreover, Kandeel et al. ${ }^{(45)}$ reported that there are an increase in the levels of oxidative stress biomarkers including NO in response to GM toxicity. NO induce renal cellular damage through formation of peroxynitrite that provoke the damage to the cellular structural molecules. However, Abdelaziz and Kandeel ${ }^{(44)}$ demonstrated that the renal toxic effect of GM mediated by increase of $\mathrm{NO}$ is ameliorated by antioxidants. In the present study, the normalization in the level of renal NO could be attributed to antioxidant activity of the Casuarina equisetifolia extract.

Preliminary phytochemical screening of Casuarina equisetifolia extract revealed the presence of alkaloids, terpenoids, flavonoids, polyphenols, steroids and tannins. Tannins are complex polyphenolic compounds widely found in higher plants. Similar to many polyphenols, tannin has been shown to possess antioxidant activity. ${ }^{(46,47)}$

The antioxidant activity of Casuarina equisetifolia extract could be also attributed to its flavonoidal content. Flavonoids act as scavengers of various oxidizing species i.e., $\mathrm{O}_{2}{ }^{--}$, ${ }^{\cdot} \mathrm{OH}$ or peroxyl radicals, they also act as quenchers of singlet oxygen. ${ }^{(48)}$ Numerous plant constituents have proven to show free radical scavenging or antioxidants activity. ${ }^{(49)}$ Phenols are very important plant constituents. There is a highly positive relationship between total phenols and antioxidant activity of many plant species, because of the scavenging ability of their hydroxyl groups. It was also reported that phenolic compounds are effective hydrogen donors, making them very good antioxidants. ${ }^{(50)}$

The potential pathological role of oxidative and nitrosative stress in renal damage was reported previously. ${ }^{(51)}$ The direct

\section{References}

1 Maliakel DM, Kagiya TV, Nair CK. Prevention of cisplatin-induced nephrotoxicity by glucoside of ascorbic acid and $\alpha$-tocopherol. Exp Toxicol Pathol 2008; 60: 521-527.

2 Kore KJ, Shete RV, Jadhav PJ. RP-HPLC method of simultaneous nephroprotective role of A. marmelos extract. Int J Res Pharm Chem 2011; 1: 617623.

3 Ali BH, Al-Wabel N, Mahmoud O, Mousa HM, Hashad M. Curcumin has a palliative action on gentamicin-induced nephrotoxicity in rats. Fundam Clin Pharmacol 2005; 19: 473-477.

4 Hou SH, Bushinsky DA, Wish JB, Cohen JJ, Harrington JT. Hospitalacquired renal insufficiency: a prospective study. Am J Med 1983; 74: 243248.

5 Paterson DL, Robson JMB, Wagener MM. Risk factors for toxicity in elderly patients given aminoglycosides once daily. J Gen Intern Med 1998; 13: 735739.

6 Uehara T, Miyoshi T, Tsuchiya N, et al. Comparative analysis of gene expression between renal cortex and papilla in nedaplatin-induced nephrotoxicity in rats. Hum Exp Toxicol 2007; 26: 767-780.

7 Lin HM, Yen FL, Ng LT, Lin CC. Protective effects of Ligustrum lucidum fruit extract on acute butylated hydroxy-toluene induced oxidative stress in rats. J Ethnopharmacol 2007; 111: 129-136.

8 Engin AB, Bukan N, Kurukahvecioglu O, Memis L, Engin A. Effect of butylated hydroxytoluene (E321) pretreatment versus L-arginine on liver injury after sub-lethal dose of endotoxin administration. Environ Toxicol Pharmacol 2011; 32: 457-464.

9 Krushna GSS, Kareem MA, Reddy VD, Padmavathi P, Hussain SA, Kodidhela LD. Aegle marmelos fruit extract attenuates isoproterenol-induced oxidative stress in rats. J Clin Biochem Nutr 2012; 50: 199-204.

10 Ahsan MR, Islam KM, Bulbul IJ, Musaddik MA, Haque ME. Hepatoprotective activity of methanol extract of some medicinal plants against carbon tetrachloride-induced hepatotoxicity in rats. Eur J Sci Res 2009; 37: 302-310.

11 Jain SK, Dam N. Some ethnobotanical notes from Northeastern India. Economic Botany 1979; 33: 52-56.

12 Ahsan MR, Islam KM, Haque ME, Mossaddik MA. In vitro antimicrobial screening and toxicity study of some different medicinal plants. Wolrd J Agri Sci 2009; 5: 617-621. contribution of ${ }^{\cdot} \mathrm{OH}$ in the pathogenesis of nephrotoxicity are also well substantiated. ${ }^{(52)}$ The nephroprotective effect of Casuarina equisetifolia extract may therefore be attributed to its potent nitric oxide and ${ }^{\circ} \mathrm{OH}$ scavenging effects. ${ }^{(53,54)}$

In conclusion, it is proposed that the nephroprotective activities of the Casuarina equisetifolia leaves extract in GM-induced nephrotoxicity may be due to presence of phytochemicals like flavonoids, tannins which may act as antioxidants individually or synergistically. Casuarina equisetifolia leaves extract could constitute a lead to discovering a novel pharmaceutical formulation which will be useful for treatment of drug-induced nephrotoxicity.

\section{Abbreviations}

$\begin{array}{ll}\text { ALT } & \text { Alanine transaminase } \\ \text { AST } & \text { Aspartate transaminase } \\ \text { DPPH } & \text { 2,2-Diphenyl-1-picrylyhydrazyl hydrate } \\ \text { GM } & \text { Gentamicine } \\ \text { GSH } & \text { Glutathione } \\ \text { GST } & \text { Glutathione-S-transferase } \\ \text { MDA } & \text { Malondialdehyde } \\ \text { NO } & \text { Nitric oxide } \\ \text { RNS } & \text { Reactive nitrogen species } \\ \text { ROS } & \text { Reactive oxygen species } \\ \text { SOD } & \text { Superoxide dismutase }\end{array}$

\section{Conflict of Interest}

No potential conflicts of interest were disclosed.

13 Khandelwal KR. Practical Pharmacognosy. Pune: Nirali Prakashan, 2006; 149.

14 Brand-Williams W, Cuvelier ME, Berset C. Use of free radical method to evaluate antioxidant activity. Lebensmittel Wissenschaf und Technologie 1995; 28: 25-30.

15 Marcocci L, Packer L, Droy-Lefaix MT, Sekaki A, Gardès-Albert M. Antioxidant action of Ginkgo biloba extract EGb 761. Methods Enzymol 1994; 234: 462-475.

16 Oyaizu M. Studies on products of browning reaction: antioxidative activities of products of browning reaction prepared from glucosamine. Jpn J Nutr 1986; 44: 307-315.

17 Smirnoff N, Cumbes QJ. Hydroxyl radical scavenging activity of compatible solutes. Phytochem 1989; 28: 1057-1060.

18 Behrens B, Karber G. Chemotherapy of Neoplastic Diseases. In: Selli C, Ckhardt S, Nmeth L, eds. Budapest: The publishing House of the Hungarian Academy, 1970; 37.

19 Jagota SK, Dani HM. A new colorimetric technique for estimation of vitamin C using Folin phenol reagent. Biochemistry 1982; 127: 178-182.

20 Lowry OH, Rosebrough NJ, Farr AL, Randall RJ. Protein measurement with the Folin phenol reagent. J Biol Chem 1951; 193: 265 (The original method).

21 Mihara M, Uchiyama M. Determination of malonaldehyde precursor in tissues by thiobarbituric acid test. Anal Biochem 1978; 86: 271-278.

22 Ellman GL. Tissue sulfhydryl groups. Arch Biochem Biophys 1959; 82: 7077.

23 Marklund SL, Marklund G. Involvement of the superoxide anion radical in the autoxidation of pyrogallol and a convenient assay for superoxide dismutase. Eur J Biochem 1974; 47: 469-474.

24 Habig WH, Pabst MJ, Jakoby WB. Glutathione S-transferases. The first enzymatic step in mercapturic acid formation. J Biol Chem 1974; 249: 7130 7139.

25 Green LC, Wagner DA, Glogowski J, Skipper PL, Wishnok JS, Tannenbaum SR. Analysis of nitrate, nitrite, and $\left[{ }^{15} \mathrm{~N}\right]$ nitrate in biological fluids. Anal Biochem 1982; 126: 131-138.

26 Silan C, Uzun O, Comunoğlu NU, Gokçen S, Bedirhan S, Cengiz M. Gentamicin-induced nephrotoxicity in rats ameliorated and healing effects of resveratrol. Biol Pharm Bull 2007; 30: 79-83.

27 Cronin RE, Thompson JR. Role of potassium in the pathogenesis of acute 
renal failure. Miner Electrolyte Metab 1991; 17: 100-105.

28 Vardi N, Parlakpinar H, Ozturk F, Acet A. Gentamicin-induced nephrotoxicity and protective effect of caffeic acid phenethyl ester in rats. Fundam Clin Pharmacol 2005; 19: 173-177.

29 Kuhad A, Tirkey N, Pilkhwal S, Chopra K. Effect of Spirulina, a blue green algae, on gentamicin-induced oxidative stress and renal dysfunction in rats. Fundam Clin Pharmacol 2006; 20: 121-128.

30 Khan SA, Priyamvada S, Farooq N, Khan S, Khan MW, Yusufi AN. Protective effect of green tea extract on gentamicin-induced nephrotoxicity and oxidative damage in rat kidney. Pharmacol Res 2009; 59: 254-262.

31 Abdel-Raheem IT, Abdel-Ghany AA, Mohamed GA. Protective effect of quercetin against gentamicin-induced nephrotoxicity in rats. Biol Pharm Bull 2009; 32: 61-67.

32 Abd-El Latif HA, Ibrahim SS, El-Yamany MF, Ali MA, Abass MM. Amelioration of gentamicin-induced nephrotoxicity by vitamin B6 in wistar rats. Egyp J Biochem Mol Biol 2008; 26: 133-149.

33 Nabavi SF, Moghaddam AH, Eslami S, Nabavi SM. Protective effects of curcumin against sodium fluoride-induced toxicity in rat kidneys. Biol Trace Elem Res 2012; 145: 369-374.

34 Harisa GI, Abo-Salem OM. Benfotiamine ameliorate gentamicin-induced nephrotoxicity: effect on renal oxidative stress markers and plasma platelets activating factor acylhydrolase activity. Int J Pharmacol 2012; 8: 364-372.

35 Pedraza-Chaverrí J, Maldonado PD, Medina-Campos ON, et al. Garlic ameliorates gentamicin nephrotoxicity: relation to antioxidant enzymes. Free Rad Biol Med 2000; 29: 602-611.

36 Dwivedi VK, Chaudhary M, Soni A, Shrivastava SM. Nephrotoxicity reduction by fixed dose combination of cephalosporins and aminoglycosides in Mus musculus mice. Asian J Biochem 2009; 4: 13-21.

37 Walker PD, Barri Y, Shah SV. Oxidant mechanisms in gentamicin nephrotoxicity. Ren Fail 1999; 21: 433-442.

38 Dean RT, Hunt JV, Grant AJ, Yamamoto Y, Niki E. Free radical damage to proteins: The influence of the relative localization of radical generation, antioxidants, and target proteins. Free Rad Biol Med 1991; 11: 161-168.

39 Schmid U, Stopper H, Heidland A, Schupp N. Benfotiamine exhibits direct antioxidative capacity and prevents induction of DNA damage in vitro. Diabetes Metab Res Rev 2008; 24: 371-377.

40 Alqasoumi S. Protective effect of Ipomea aquatica forsk on gentamicininduced oxidative stress and nephropathy in rats. Topclass J Herb Med 2013;
2: 13-19.

41 Shirwaikar A, Issac D, Malini S. Effect of Aerva lanata on cisplatin and gentamicin models of acute renal failure. J Ethnopharmacol 2004; 90: 81-86.

42 Kim DO, Chun OK, Kim YJ, Moon HY, Lee CY. Quantification of polyphenolics and their antioxidant capacity in fresh plums. J Agric Food Chem 2003; 51: 6509-6515.

43 Rivas-Cabañero L, Montero A, López-Novoa JM. Increased glomerular nitric oxide synthesis in gentamicin-induced renal failure. Eur J Pharmacol 1994; 270: 119-121.

44 Abdelaziz I, Kandeel M. The protective effects of Nigella sativa oil and Allium sativum extract on amikacin-induced nephrotoxicity. Int J Pharmacol 2011; 7: 697-703.

45 Kandeel M, Abdelaziz I, Elhabashy N, Hegazy H, Tolba Y. Nephrotoxicity and oxidative stress of single large dose or two divided doses of gentamicin in rats. Pak J Biol Sci 2011; 14: 627-633.

46 Amarowicz R, Naczk M, Shahidi F. Antioxidant activity of crude tannins of canola and rapeseed hulls. J Am Oil Chem Soc 2000; 77: 957-961.

47 Tebib K, Rouanet JM, Besançon P. Antioxidant effects of dietary polymeric grape seed tannins in tissues of rats fed a high cholesterol-vitamin E-deficient diet. Food Chem 1997; 59: 135-141.

48 Das NP, Ratty AK. Effect of flavonoids on induced non-enzymatic lipid peroxidation. In: Cody V, Middleton E, Harborne J, eds. Plant flavonoids in Biology and Medicine: Biochemical, Pharmacological and Structure-Activity Relationships. New York: Liss AR, 1986; 243-247.

49 Hall CA III, Cuppett SL. Structure-activities of natural antioxidants. In: Aruoma OI, Cuppett SL, eds. Antioxidant Methodology: In Vivo and In Vitro Concepts. AOCS press, 1998; 141-172.

50 Vinson JA, Hao Y, Su X, Zubik LS. Phenol antioxidant quantity and quality in foods: vegetables. J Agric Food Chem 1998; 46: 3630-3634.

51 Goligorsky MS, Brodsky SV, Noiri E. Nitric oxide in acute renal failure: NOS versus NOS. Kidney Int 2002; 61: 855-861.

52 Singh P, Srivastava MM, Khemani LD. Renoprotective effects of Andrographis paniculata (Burm. f.) Nees in rats. Ups J Med Sci 2009; 114: 136-139.

53 Kumaran A, Karunakaran RJ. Nitric oxide radical scavenging active components from Phyllanthus emblica L. Plant Foods Hum Nutr 2006; 61: 1-5.

54 Strlic M, Radovic T, Kolar J, Pihlar B. Anti- and prooxidative properties of gallic acid in fenton-type systems. J Agric Food Chem 2002; 50: 6313-6317. 